\title{
Analysis on the Reform Path of China's Trade Union System
}

\author{
Liang-shan $\mathrm{LI}^{1, \mathrm{a},{ }^{*}}$ \\ ${ }^{1}$ Inner Mongolia finance and economics university, Hohhot, \\ Inner Mongolia, P.R. China \\ aLiliangshan3@126.com
}

Keywords: New normal, Trade union, System reform.

\begin{abstract}
The Third Plenary Session of the 18th Central Committee put forward the market to play a decisive role in the allocation of resources to the six areas of the CPC Central Committee to deepen the reform and the establishment of a leading group for further market-oriented reforms lay a solid foundation. In this round of comprehensive reform of the process of deepening the economic field of the new normal, the ruling concept of our party had a profound impact.
\end{abstract}

\section{Introduction}

Under the new economic normal, the contradiction between labor and capital is becoming more and more prominent, and the urgency of the trade union in market-oriented reform is becoming more and more obvious. On November 9th, 2015, General Secretary Xi Jinping hosted the 18th meeting of the Central Leading Group for Deepening Reform and made an important speech. At the meeting, the "Reform Program of the National Federation of Trade Unions" was reviewed and adopted and the reform of trade union system prelude.

\section{Labor NGO's Challenge to Trade Union System of China}

However, the external pressure of the labor NGO on the trade union system in China is obvious, regardless of whether there is a transition from individual labor relations to collective labor relations.

There are two kinds of forces and two paths in the transformation of labor relations in China: one is the trade union movement within the system dominated by the party and government, and the other is the collective labor relation from the top-down administrative way and way; The labor movement outside the system, which is formed spontaneously by the laborers, promotes the transformation of labor relations by means of bottom-up popularization. As a spontaneous labor organization, labor NGO actively participates in labor affairs and has a certain influence in the laborers in the bottom, which will be an external unstable factor to our country's future labor relations. Deep concern.

\section{The Rapid Development of China 's Labor NGO Organization}

China's social organizations mainly include social groups, private non-enterprise units, foundations in three forms. As of the end of 2012, the country registered a total of 490,000 social organizations, including 267,000 social groups, private non-enterprise units 220,000, 2963 Foundation. In addition, there are a large number of overseas social organizations in China activities, China's long-term activities of overseas NGO around 1000 , together with the short-term cooperation project organization, the total may have 
reached about 7000. It provides financial and technical support to domestic NGO, directly or indirectly, and has made some achievements with respect to labor NGO, but there are also many problems.China's Pearl River Delta region specializing in labor rights protection workers of the NGO organizations about more than 30, of which more influential are the following institutions: Panyu Working Family Service department, Shenzhen Spring Labor Dispute Services, Guangzhou Xiangyang Social Work Services Center, a Small Grass in Shenzhen, the workers home and Guangdong Lawyers Law Firm. These NGO organizations have survived in China, with 569 cases of labor protests occurring in the fourth quarter of 2014, according to a Hong Kong-based China Labor Bulletin.

This is three times the number of strikes in the same period in 2013, compared with 2011, a huge increase in 2011, the year recorded only 185 labor protests. A large number of workers based on the needs of rights, eager to get professional legal services, but because of labor disputes involving multiple interests of the complexity and political sensitivity and other reasons, professional lawyers do not want to get involved. Professional lawyers do not want to agents, leaving the market blank filled by non-professionals. A large number of non-professionals and lawyers who are sympathetic to the labor force have entered the field of labor rights non-governmental organizations.High labor collective action provides a broad space for the transformation of labor NGO functions. Some labor NGO are aware of this opportunity for development and transformation and attempt to complete the transformation in the practice of collective action of workers, that is, transformation from a service organization For the type of organization. In order to obtain better labor and employment conditions, the social insurance benefits, such as the employment of workers, the employment of workers and workers, the employment of workers and workers, Implement mobilization, organize workers to participate in collective action. As the transfer of the functions and work centers from the individual labor relations into the collective labor relations of enterprises will inevitably conflict with the existing trade union system and the local community management regulations, it becomes an insurmountable institutional obstacle for the labor NGO to participate in the collective labor conflicts. How to deal with the relationship between labor NGO and government organizations, how to guide them, help to achieve the harmonious labor relations, which need to test the political wisdom of all levels of government.

\section{The External Pressure of Labor NGO on the Trade Union System of China}

Labor NGO laws and imperfections of the relevant laws and practices of employees can't lead to problems. Term operation of institutions is not standardized, resulting in heavy and hard to return to conflict with our laws, bound to be bound by the law. The urgent need for the rights of workers and the interest of the overseas NGO in China's huge market have led to the rapid development of the domestic labor NGO. However, the NGO organizations in the gray areas of the existing laws and regulations in China lack the necessary Legal basis and local government support, so as to choose more extreme means to rapid development, hoping to arouse public concern, in the working group to win the reputation, and then for its existence to provide public opinion support. In the form of active intervention, labor NGO take the basic rights of laborers to higher interests and strive to raise the demands that are contrary to laws and regulations. Workers are encouraged to take more violent strikes and demonstrations to put pressure on local governments. Concessions, so that labor negotiations out of the factory this field. Compared with the unions of the trade unions, the local trade unions dare not, the 
labor NGO action strategy for its win a certain social prestige, but also to alienate workers and trade unions. The potential challenges to the political stability of our target groups and the areas in which they are served by labor NGO are a matter of constant constraint by governments at all levels. Labor NGO is a high degree of political threat, high degree of social-economic service organizations, such organizations, if not control, the organization's political mobilization capacity will present a great threat to the regime. Strict legal restraints on labor NGO at home and abroad are bound to reduce their living space in our country and even die out. For labor NGO, we need to recognize that, despite the problems of legality of registration, sources of funds, and business normality, the contribution of labor NGO to the protection of the labor rights of bottom-class workers over the years is worthy of recognition. If we restrict or even restrict the development of our country's political system on the basis of its negative influence on our political system, the gaps in the past, which have been filled by labor NGO, must be compensated by the reform of the trade union system. Will only lead to low-level worker's dissatisfaction with the trade union system, thereby affecting China's social stability. This reality also needs to increase the urgency of the deepening reform of China's trade union system, change the work style, from the masses to the masses, and effectively become an umbrella of workers, which also reflects the reform from the trade union under the important.

But we must see more labor NGO adopt radical activist means to expand the situation, rather than at the negotiating table in a rational collective bargaining approach to resolve, is bound to undermine China's economic order, challenge our existing labor relations operating mechanism.

\section{China 's Trade Union Reform under the New Economic Normal}

\section{The Importance of China 's Trade Union Reform under the New Normal}

Under the new normal industry transformation and upgrading, enterprise innovation can not do without good employees, the realization of green GDP is not built on the basis of labor-intensive foundry industry, and this all determines the enterprise employment must be changed, labor relations Of the long-term will become its main features, the establishment of the core workforce has become the fundamental survival. At the same time, the attitude of governments at all levels of the face of capital must also be changed, the transformation and upgrading of industry, innovation is not by exploiting workers surplus surplus value sweatshops can bear, strict labor law enforcement is the inevitable choice under the new normal, This also laid the foundation for the transition from microscopic to macroscopic in the field of labor relations.

In this innovation-driven industrial transformation and upgrading process, high-skilled workers with the enterprise's attention to talent, will get a better career prospects. As for the workers with only simple operation skills, with the increase of labors 'labor costs, a large number of labor OEM relocated and closed down frequently, which will inevitably produce to 200 million migrant workers' groups in China. Substantive impact. The fate of front-line workers determines the process of urbanization in China and determines the improvement of the quality of life of the rural population, which is the overwhelming majority of the population of China, and the confidence of the masses in the party and the government. This is an inevitable requirement for our Party to consolidate its ruling position. Industrial upgrading is not only the transformation of production methods, but also the working group of workers 
to enhance the level of production skills, which is a comprehensive process of upgrading workers. How to ensure the realization of workers' right to employment, how to ensure the realization of the legitimate rights and interests of employees in the enterprise layoffs, how to ensure that the workers in the industrial disputes in the process of industrial disputes, how to ensure that the workers in the industrial chain of the bottom of the workers, In a solemn stand, a strong backing of the workers. All this requires that the All-China Federation of Trade Unions (ACFTU) in this new normal state change their style, fulfill their duties and shoulder the responsibilities of the workers' defenders. This is also the problem to be solved in deepening the reform of the trade union system.

\section{The Urgency of Trade Union Reform in China under the New Normal}

The harmony of labor relations in our country lies in whether the trade unions can fulfill their duties effectively. It is also a social consensus that the trade union system should play a maintenance function in harmonious labor relations. ACFTU model a lot of advantages, such as in the policy making process can be a good voice, to ensure the protection of labor rights laws and regulations to be implemented. This trade union model of the top-down its lack of Needless to say, as the Shanghai Trade Union President pointed out that trade unions own problems: "organization, the tendency of administrative objective existence, more prominent, the concept of the masses is not strong, the masses The position of workers is not clear, the work of safeguarding the rights is not enough, the affinity, cohesion and appeal of the work organizations have declined, and the masses of workers and trade unions have gradually drifted further away from them. "The administrative union system, the monopoly right of the trade union system, Inverted pyramid, and organizational mobilization capacity from the continuous weakening, resulting in the most in need of trade unions play a role in the grass-roots trade unions have a lack of influence, decided to work their thinking on the $\mathrm{CD}$, the workers involved in the local group stability All the action to listen to the negative attitude of the work and many other issues led to the grassroots trade unions away from the workers drifting away, but also reflects the trade union system of the current new normal response to fatigue, the majority of workers criticized by the masses.

This practical need also increases the urgency of deepening reform of China's trade union system, changing the work style, from the masses to the masses, and effectively become the umbrella of the workers. Under the normal economic conditions, the success of China's trade union system reform determines the process of market-oriented reform, and only an effective trade union organization can deal with an increasing number of collective labor conflicts. The reform of the trade union system should make a fuss about itself, that is, to give up the vested interests of the department, not merely in form, but also to seek the innovation of the mechanism of safeguarding rights within the framework of our legal system. This requires pain, open the door unions, in exchange for the stability of society as a whole, in-depth service for the reform.

\section{Discussion on the Reform Path of Trade Union System under the New Normal}

\section{Specialization of Trade Union Cadres}

The nature of the civil servants of the trade union staff in our country determines that the cadres of the trade unions will be selected from the enterprise union. However, due 
to the particularity of the work of the trade unions, it is necessary for the practitioners to have relevant working background and work experience, and it is particularly important for them to have deep feelings for the working class. This feeling is based on empathy, rather than a simple induction education and theoretical study can be replaced. The mobilization of enterprise trade union formation and the solution of staff's demands all need a large number of professional trade union cadres with grass-roots work experience. It is an effective way for trade unions to professionalize their trade union. In addition, to increase the training of trade union cadres, master the work of the labor laws and regulations, learning and communication with the enterprise workers clever. Only the professional, dare to play the trade union cadres to form, is the core of the reform of trade unions system. Therefore, it is necessary to establish a system of labor union coordinators qualification mechanism, from the professional competence to the accumulation of work experience and other indicators of assessment.

\section{Administrative Change of the Way of Trade Union Work}

It is necessary to consider the attitude of the local party and government, but also to consider the reaction of the trade union at the higher level, so as to make the normalization of the inaction as the normalization of the trade union's selection and examination mechanism. Before the collective labor conflicts occurred, the workers can not find the union cadres, after the occurrence of local party and government consent only after the involvement of the identity of the coordinator, rather than the rights and interests of workers on behalf of the local labor union is not the absence of labor union Contradiction to resolve in the bud, resulting in the maintenance of stability costs. Under the systematization of labor and capital interests are clear, and the planned economic interests of the integration of labor relations are essentially different, determines the union must stand in the position of workers to think, only to remove the administrative mode of behavior can achieve a fundamental change. The deepening reform of the trade union system, to remove the union chairman in the administrative system of administrative duties, only their own accurate positioning, to better perform their duties. The bottom-up empowerment will also help to deal with the relations between trade unions at the grass-roots level and the trade unions of enterprises, from management to service. Changing the inverted pyramid of resource allocation within the trade unions, tilting the resources in the enterprise unions, and giving the evaluation rights of trade unions above the grass-roots level to the trade unions.

\section{The Transparency of the Use of Union Funds}

Since the implementation of the reform of the financial system of trade unions in 2004, the taxation departments have provided adequate financial support for the trade union work in China. However, the annual amount of this funding has not been released through official channels, according to media sources pointed out that the total funds of more than 20 billion, of which $40 \%$ to be allocated to the higher trade unions. In the past, labor unions had difficulty in collecting such funds, which resulted in enterprises gaining more voice in the labor and capital game. Nowadays, the mode of collection by administrative means ensures the independence of trade unions' rights protection. However, the transformation of the mode of collection of funds, the union is no longer dependent on the economic side of the capital, membership dues are not binding on it, resulting in transcendence of the total allegiance to both sides, the administrative characteristics of the more obvious. For the use of trade union funds, the All-China Federation of Trade Unions promulgated the Measures for the Use of Funds at the Basic 
Level, while the use of trade union dues at the county level was supervised by the funds inspection committee at the same level. The unionization of funds and the non-transparency of the use of funds will inevitably lead to the questioning of the society. Although this questioning will not have any influence on the administrative means of payment, it is unfavorable for the development of trade unions. The mass base of the trade unions, the lack of trade union support of the masses of workers is the source of water without a tree. The use of union funds in the future to increase the proportion of grass-roots trade unions, commissioned a third party professional audit institutions to monitor, regularly published in the form of the official gazette. In addition, the use of trade union funds to solicit opinions at all levels, or just entertain, talk to oneself.

\section{The Information System to Trade Unions}

China's rapid Internet promotion, the popularity of mobile terminals, an increase of the mobilization of workers groups organizational capacity, instant access to information, information dissemination and convenient management of enterprise labor relations put forward higher requirements. As a trade union system, it is necessary to grasp the potential opportunities brought by the Internet for the trade union reform. Through the site, the use of mobile phone APP, the union on the one hand can release the latest laws and regulations, dissemination of positive energy so that rumors have not been able to spread space. On the other hand, the use of instant mobile terminal APP can enable enterprise trade union members and grass-roots trade union cadres to communicate with higher-level trade union departments in real time and resolve the potential instability in the workplace. At the same time, the two-way communication eliminates the trade union and members Of alienation. In addition, through the Internet platform can establish a bottom-up supervision and restraint mechanism for local trade unions, employees of the enterprises of improper labor behavior of real-time complaints, grassroots trade unions of the rapid linkage, higher trade union organizations on the progress of the event, the results of monitoring, The Initiative of Trade Union 's Safeguarding Rights. Confronted with the misconduct of trade unions and local labor unions in the conflict of labor and capital, it is possible to establish a leapfrog complaint mechanism within the trade union system and to effectively restrain the behavior of trade union cadres.

\section{Acknowledgement}

This research was financially supported by the National Science Foundation: 13 XSH023

\section{References}

[1] E·kaufman, labor and Employment Regulation: Neoclassical and Institutional

[2] Barbash, Collective Bargaining: Contemporary American Experience Reading in Labor Economics and Labor Relations. Ed Lloyd

[3] Barging Equanimity Industrial Relations, American labor law, 1992 